\title{
Significant Elevation of Tumour-Associated Isoforms of Soluble CD44 in Serum of Normal Individuals Caused by Cigarette Smoking ${ }^{1}$ )
}

\author{
Eva Maria Kittl ${ }^{1}$, Reinhard Ruckser ${ }^{2}$, Irene Rech-Weichselbraun ${ }^{3}$, Wolfgang Hinterberger $^{2}$ and Kurt Bauer ${ }^{1}$ \\ ${ }^{1}$ Institut für Labormedizin, Donauspital, Wien, Austria \\ 2 2. Medizinische Abteilung, Donauspital, Wien, Austria \\ 3 Abteilung für Forschung und Entwicklung, Bender MedSystems Wien, Wien, Austria
}

Summary: While performing a prospective study on SCD44 variant isoforms as tumour markers in certain malignancies, we detected relevant differences in the control group between non-smokers and smokers. For a detailed evaluation of these findings, serum levels of sCD44 variant proteins, including sequences encoded by exon v 5 and exon v6, respectively, were adjusted to sex, age and smoking habit.

We were able to demonstrate a significant elevation of serum levels of sCD44v5 and sCD44v6 in normal individuals due to cigarette smoking (non-smokers to smokers: sCD44v5: $33 \pm 11 \mu \mathrm{g} / 1$ to $62 \pm 30 \mu \mathrm{g} / \mathrm{l}$; sCD44v6: $142 \pm 34 \mu \mathrm{g} / 1$ to $232 \pm 86 \mu \mathrm{g} / \mathrm{l})$. Stepwise multiple linear regression analysis of the concentrations of sCD44v5 and $\mathrm{sCD} 44 \mathrm{v} 6$ on the possible influence factors sex, age and smoking habit revealed cigarette smoking as the only factor influencing these isoforms (both $\mathrm{p} \ll 0.001$ ). Further investigations have to elucidate a possible clinical importance of these findings in smokers. However, in patients with suspected or proven malignancy the diagnostic specifity of sCD44v5 and sCD44v6 is diminished due to this observation.

\section{Introduction}

CD44 is a widely-expressed cell surface glycoprotein that mediates a variety of adhesive processes in ceilcell and cell-matrix interactions (1-5). The pleiotropic molecular interactions are mediated by different isoforms generated by alternative RNA splicing of at least 10 variably-expressed exons, mainly encoding extracellular regions $(6,7)$.

The role of CD44 in metastatic disease has been elucidated by the detection of splice variants on metastatic cells. Based on data obtained with a spontaneous rat metastasis assay, CD44 splice variants (sharing an epitope within the sequence of exon v6) have been identified to be functionally involved in tumour dissemination (8). Variant isoforms have recently been shown to be expressed on the surface of a variety of human tumours (9-14). The causal involvement of CD44 variants in the complex process of metastasis formation was strengthened by the relation of their expression with tumour progression in colorectal cancer, and as a poor prognostic factor for overall survival in breast cancer and in non-Hodgkin's-lymphoma, respectively $(15-17)$.

Besides tissue expression, soluble CD44 variant isoforms are detectable in human serum. Serum levels of

\footnotetext{
1) Funding: The work was supported in part by Bender MedSystems Vienna, Vienna, Austria
}

sCD44 have been proven to be correlated with tumour load and metastasis in serum of patients with gastric or colon cancer (18). Measurement of sCD44 variant proteins could be useful as a tumour marker in patients with certain solid cancers and haematological malignancies.

We started a prospective study on sCD44v5 and sCD44v6 to evaluate the clinical relevance of these new markers in the diagnosis and follow-up of patients with certain malignancies. While defining a large control group of normal individuals, we realized elevated serum levels for both markers in healthy serum donors who demonstrated extreme smoking habits. This led us to define the influence of nicotine abuse on serum concentrations of soluble CD44 variant isoforms in normal individuals.

\section{Materials and Methods}

Serum samples

Blood was drawn by venipuncture from 147 voluntary, healthy human donors after informed consent was given and centrifuged immediately. The serum samples were kept at $-20^{\circ} \mathrm{C}$ prior to assay.

Enzyme-linked immunosorbent assay for sCD44v5 and sCD $44 \mathrm{v} 6$

A commercially available sandwich type ELISA, developed by Bender MedSystems Vienna, Vienna, Austria, was used for the quantitative measurement of sCD44v5 and sCD44v6 in human se- 
rum. A monoclonal antibody specific for an epitope of the CD44 standard molecule served as the capturing antibody adsorbed to microplates. An antibody specific for the splice variant tested (VFF8 for an epitope encoded by exon v5, VFF18 for an epitope encoded by exon v6) coupled to horseradish peroxidase was used for signal-generating by the peroxidase/tetramethyl-benzidine system.

The ELISA tests were performed according to the manufacturers instructions: Briefly, samples were prediluted with sample diluent (buffered protein matrix containing $0.1 \mathrm{~g} / 1$ thimerosal as preservative) $1+5$ for the sCD44v5 assay and $1+19$ for the sCD44v6 assay. Microwell strips were washed twice with $10 \mathrm{ml} / 1$ Tween20 in phosphate-buffered saline. After reconstitution of lyophilized CD44 variant standards $(20 \mu \mathrm{g} / \mathrm{l}), 100 \mu \mathrm{l}$ of sample diluent were added in duplicate to the appropriate standard wells. The standard protein for both assays in eukariotically (CHO cell line: ovary, Chinese hamster) expressed recombinant protein containing the variant sequences $(12,19)$. Standard dilutions were prepared in duplicate by pipetting $100 \mu \mathrm{l}$ of the corresponding CD44 standard into the first standard wells; serial dilutions ranging from 10 to $0.32 \mu \mathrm{g} / 1$ were created by transferring $100 \mu \mathrm{l}$ from well to well. From the last wells $100 \mu \mathrm{l}$ were discarded. Sample diluent $(100 \mu \mathrm{l})$ was added to the blank wells. After adding $80 \mu$ l of sample diluent to the sample wells, $20 \mu \mathrm{l}$ of prediluted samples were pipetted in duplicate to the designated wells (giving a final dilution of $1+29$ for sCD44v5 and $1+99$ for sCD44v6). The corresponding horseradish peroxidase conjugate $(50 \mu \mathrm{l})$ was added to all wells. Incubation was performed at room temperature for 3 hours on a rotator platform $\left(100 \mathrm{~min}^{-1}\right)$ followed by three washing steps. Colour development was performed with $100 \mu \mathrm{l}$ substrate solution $\left(3,3^{\prime}, 5,5^{\prime}-\right.$ tetramethyl-benzidine, Kirkegaard and Perry Laboratories, Inc, Gaithersburg, USA, and $0.2 \mathrm{~g} / 1$ buffered hydrogen peroxide) for 15 minutes and the peroxidase reaction was then stopped by adding $100 \mu \mathrm{l}$ of $2 \mathrm{~mol} / 1 \mathrm{H}_{2} \mathrm{SO}_{4}$. The microwell reader was blanked and colour intensity was measured at $450 \mathrm{~nm}$ (ELISA-reader anthos htII, anthos labtec instruments, Salzburg, Austria).

An evaluation of the reproducibility of sCD $44 \mathrm{v} 5$ and sCD44v6 values in our laboratory for two sera gave the following coefficients of variation: within-assay $(\mathrm{n}=10): 4.6 \%$ (mean concentration: 56 $\mu \mathrm{g} / \mathrm{l}$ ) and $3.2 \%$ (mean concentration: $127 \mu \mathrm{g} / \mathrm{l}$ ) for sCD44v5 determinations, $1.3 \%$ (mean concentration: $230 \mu \mathrm{g} / 1$ ) and $2.4 \%$ (mean concentration: $392 \mu \mathrm{g} / \mathrm{l}$ ) for sCD44v6 determinations, between-assay $(\mathrm{n}=12): 5.9 \%$ (mean concentration: $56 \mu \mathrm{g} / \mathrm{l}$ ) and $6.9 \%$ (mean concentration: $127 \mu \mathrm{g} / \mathrm{l}$ ) for sCD44v5 determinations, $5.2 \%$ (mean concentration: $230 \mu \mathrm{g} / \mathrm{l}$ ) and $8.8 \%$ (mean concentration: $392 \mu \mathrm{g} / \mathrm{l}$ ) for $\mathrm{sCD} 44 \mathrm{v} 6$ determinations. These results are in accordance with the data published by the manufacturer. Further performance characteristics regarding sensitivity, specifity, recovery studies and comparison of serum and plasma are given in the package inserts included in the test kits $(20,21)$.

\section{Statistics}

Results are described by means, medians and standard deviations. The relations between sex, age and smoking habit have been investigated by t-test, by analysis of variance (ANOVA) and by Chisquare-test. The dependence of sCD44v5 and sCD44v6 on age, sex and cigarette smoking has been analyzed by stepwise multiple linear regression analysis (Superior Performing Statistical Software SPSS 6.0 inc., Chicago, Illinois 1993).

\section{Results}

The concentrations of $\mathrm{sCD} 44 \mathrm{v} 5$ and $\mathrm{sCD} 44 \mathrm{v} 6$ were measured in serum samples of unselected healthy donors. First results showed an excessive positive skewness for both markers implicating a bimodal distribution that could not be explained by sex or age $(n=125$, data not shown). Subsequently, the distribution of sCD44v5 and sCD44v6 in 147 additional voluntary human serum donors was analyzed with respect to the smoking habits. Characteristics of serum donors are given in table 1. The samples of all smokers $(n=51)$ were further assigned to two groups according to the number of cigarettes smoked per day: group I $(n=44)$ : $5-20$ cigarettes per day; group II $(n=7):>20$ cigarettes regularly per day in agreement with the persons assertions. With respect to the variables age, sex and smoking habit, the samples were distributed equally (two-sided comparison of the average age between sex, $t$-test, $p=0.98$; comparison of average age between non-smokers and smokers, analysis of variance, $p=0.63$; Chi-square-test for sex versus smoking habit, $p=0.30$ ). The distributions of $\mathrm{sCD} 44 \mathrm{v} 5$ and $\mathrm{sCD} 44 \mathrm{v} 6$ concentrations in serum samples are shown for non-smokers and all smokers (including group I and group II) in figure 1 and figure 2, respectively. Means, medians and standard deviations are given in table 2, including separate estimates for the two subgroups of smokers. For both sCD44 isoforms the data show a marked dependence on smoking habits. Stepwise multiple linear regression analysis of the concentrations of sCD44v5 and sCD44v6 on the possible influence factors sex, age and smoking habit revealed cigarette smoking and its intensity as the only factors influencing these isoforms (both $\mathrm{p} \ll 0.001$ ). No dependence on sex or age was found (sCD44v5: sex, $p=0.92$, age, $\mathrm{p}=0.64$; sCD44v6: sex, $\mathrm{p}=0.90$, age, $\mathrm{p}=0.79$ ).

\section{Discussion}

We were able to demonstrate a significant elevation of serum concentrations of sCD44v5 and sCD44v6 in normal individuals who smoke cigarettes. As much as $37 \%$ of the biological variability of sCD $44 \mathrm{v} 5$ and $36 \%$ of the biological variability of sCD44v6 serum levels are explained by a linear trend on cigarette smoking alone.

The cellular origin of sCD44 variant isoforms in human serum is not yet known. Theoretically, the soluble isoforms might result from proteolytic release of the extracellular domain or by alternative splicing that leads to mRNA encoding only the extracellular domain. Because mRNA splice variants corresponding to the extracellular domain alone have not yet been reported, CD44 proteins

Tab. 1 Characteristics of healthy serum donors

\begin{tabular}{|c|c|c|c|c|c|}
\hline & \multirow{2}{*}{$\begin{array}{l}\text { Sample } \\
\text { size }\end{array}$} & \multirow{2}{*}{$\begin{array}{l}\mathrm{Age}^{\mathrm{a}} \\
\text { (a) }\end{array}$} & \multirow{2}{*}{$\begin{array}{l}\text { Non- } \\
\text { smok- } \\
\text { ers }\end{array}$} & \multicolumn{2}{|c|}{ Smokers } \\
\hline & & & & $\mathrm{I}^{\mathrm{b}}$ & II $^{\mathrm{c}}$ \\
\hline Total & 147 & $38.1( \pm 10)$ & 96 & 44 & 7 \\
\hline Male & 80 & $38.2( \pm 10)$ & 48 & 27 & 5 \\
\hline Female & 67 & $38.1( \pm 10)$ & 48 & 17 & 2 \\
\hline
\end{tabular}

\footnotetext{
${ }^{\text {a }}$ Means \pm SD are given

b group I: $5-20$ cigarettes per day,

c group II: $>20$ cigarettes regularly per day.
} 


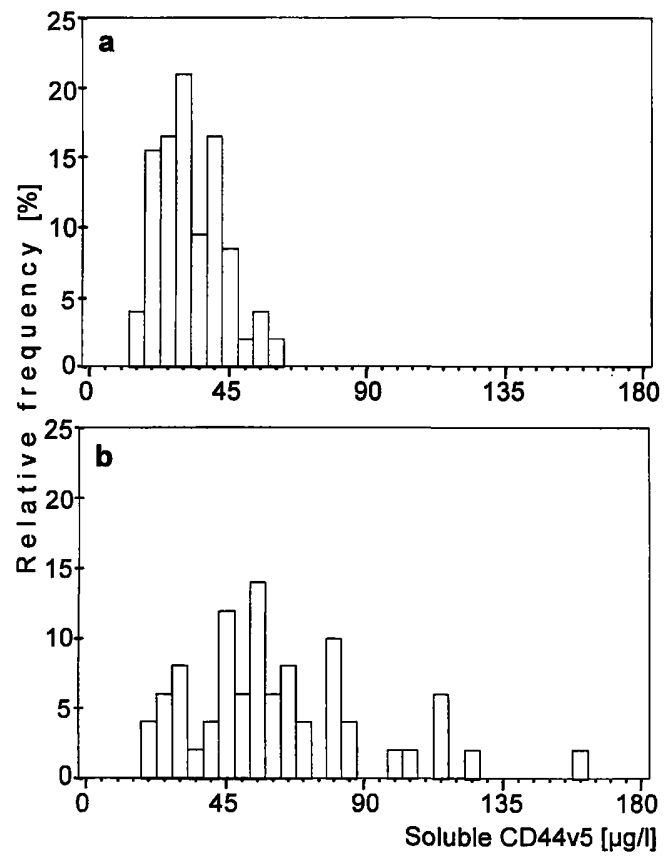

Fig. 1 Histogram of relative frequencies of sCD44v5 concentrations in serum samples from 147 normal human individuals with regard to smoking habits. a. Non-smokers $(n=96)$, b. Smokers $(n=51)$, see also table 2 .

seem to be released into the blood by shedding from vital cells or by proteolytic release of decaying cells. Whether or not SCD44 molecules retain biological function comparable to other soluble forms of cellular adhesion molecules remains unkown (22).

Strong expression of CD44v5 and CD44v6 is detectable in bronchial epithelium and pneumocytes type II in normal human lung tissue $(10,19)$. Expression of CD44 splice variants might be upregulated in these cells in chronic nicotine abusers. However, these epithelia are endoluminal and shedding from these cells into the circulation is thought to be inhibited by the intact basal membrane. Therefore, elevated serum levels of sCD44 variant proteins in individuals who smoke cigarettes are unlikely to be caused by shedding of CD44 isoforms from these cells.

Another explanation for elevated serum concentrations of sCD44 variant isoforms in smokers could be due to
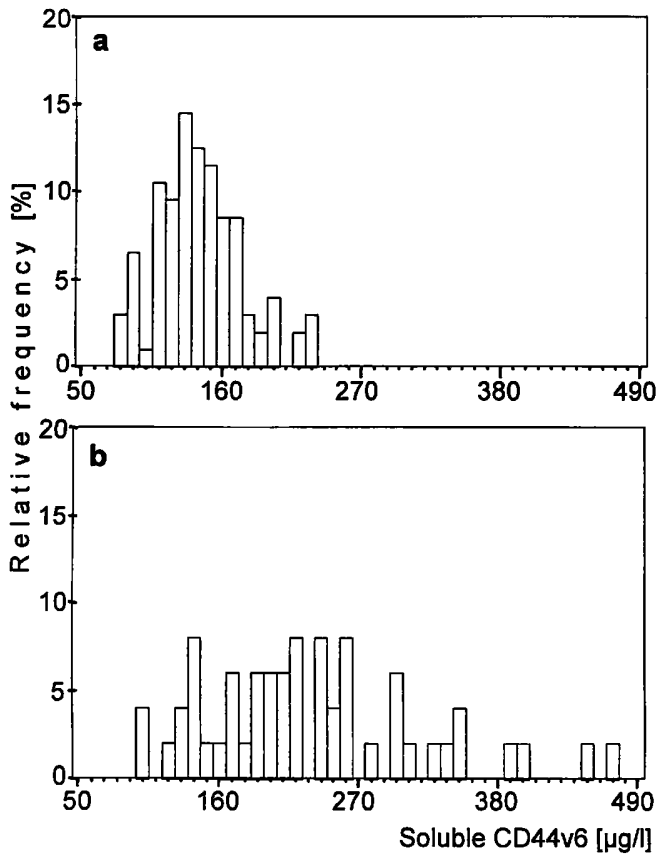

Fig. 2 Histogram of relative frequencies of $\mathrm{sCD} 44 \mathrm{v} 6$ concentrations in serum samples from 147 normal human individuals with regard to smoking habits. a. Non-smokers $(n=96)$, b. Smokers $(\mathrm{n}=51)$, see also table 2 .

the chronic bronchial inflammation. CD44 molecules are involved in multiple proinflammatory steps including $\mathrm{T}$ cell activation, $\mathrm{T}$ cell adhesion to monocytes, cytokine release and regulation of the function of other adhesion molecules $(1-5,23)$. Upregulation of CD44 splice variants on myelomonocytic cells and human endothelial cells has been reported in response to the inflammatory cytokines tumour necrosis factor- $\alpha$ (TNF $\alpha$ ) and interferon- $\gamma(\operatorname{IFN} \gamma)(4,23)$. The effect of these cytokines on CD44 expression was also examined on epithelial cells (upregulation of CD44v6 by IFN $\gamma$ ) and fibroblasts (upregulation of a molecule, structurally related to $\mathrm{CD} 44$, by $\mathrm{TNF} \alpha$ ). In immunohistochemical analysis pulmonary macrophages were stained by a monoclonal antibody targeting sequences of exon v6 (23). Thus elevated serum levels may result from the activation of proinflammatory pathways in nicotine-distressed lungs. Smoking considerably elevates the concentration of sCD44v5 and sCD44v6 in the circulation. Further in-

Tab. 2 ELISA measurements of sCD44v5 and sCD44v6 concentrations in normal human serum samples, analyzed with regard to smoking habits

\begin{tabular}{|c|c|c|c|c|c|c|c|}
\hline & \multirow[t]{2}{*}{ Sample size } & \multicolumn{3}{|c|}{$\begin{array}{l}\text { sCD44v5 } \\
(\mu \mathrm{g} / \mathrm{l})\end{array}$} & \multicolumn{3}{|c|}{$\begin{array}{l}\text { sCD44v6 } \\
(\mu \mathrm{g} / 1)\end{array}$} \\
\hline & & mean & median & SD & mean & median & SD \\
\hline Non-smokers & 96 & 33 & 30 & 11 & 142 & 140 & 34 \\
\hline $\begin{array}{l}\text { All smokers } \\
\text { Group I }{ }^{\mathrm{a}} \\
\text { Group } \mathrm{II}^{\mathrm{b}}\end{array}$ & $\begin{array}{r}51 \\
44 \\
7\end{array}$ & $\begin{array}{l}62 \\
59 \\
79\end{array}$ & $\begin{array}{l}56 \\
56 \\
55\end{array}$ & $\begin{array}{l}30 \\
27 \\
44\end{array}$ & $\begin{array}{l}232 \\
227 \\
266\end{array}$ & $\begin{array}{l}215 \\
216 \\
215\end{array}$ & $\begin{array}{r}86 \\
82 \\
107\end{array}$ \\
\hline
\end{tabular}

${ }^{a}$ group I: $5-20$ cigarettes per day; ${ }^{\text {b }}$ group II: $>20$ cigarettes regularly per day. 
vestigations have to elucidate a possible biological importance of these findings in smokers. However, in patients with suspected or proven malignancy the diagnostic specifity of sCD44v5 and sCD44v6 is considerably diminished due to our observation.

\section{References}

1. Lesley J, Hyman R, Kincade PW. CD44 and its interaction with the extracellular matrix. Adv Immunol 1993; 54:271335.

2. Underhill C. CD44: the hyaluronan receptor. J Cell Sci 1992; 103:293-8.

3. Springer TA. Adhesion receptors of the immune system. Nature 1990; 346:425-34.

4. Webb DSA, Shimizu Y, van Seventer GA, Shaw S, Gerrard TL. LFA-3, CD44 and CD45: physiological triggers of human monocyte TNF and IL-1 release. Science 1990; 249:1295-7.

5. Haynes BF, Telen MJ, Hale LP, Denning SM. CD44 - a molecule involved in leukocyte adherence and T-cell activation. Immunol Today $1989 ; 10: 423-8$.

6. Haynes BF, Liao HX, Patton KL. The transmembrane hyaluronate receptor (CD44): multiple functions, multiple forms. Cancer Cells $1991 ; 3: 347-50$.

7. Gunthert U. CD44: a multitude of isoforms with diverse functions. Curr Top Microbiol Immunol 1993; 184:47-63.

8. Gunthert U, Hofman M, Rudy W, Reber S, Zöller M, Haubmann 1 , et al. A new variant of glycoprotein CD44 confers metastatic potential to rat carcinoma cells. Cell 1991; 65:13-24

9. Hofmann M, Rudy W, Zoller M, Tolg C, Ponta H, Herrlich H, et al. CD44 splice variants confer metastatic behavior in rats: homologous sequences are expressed in human tumor cell lines. Cancer Res 1991; 51:5292-7.

10. Fox SB, Fawcett J, Jackson DG, Collins I, Gatter KC, Harris $\mathrm{AL}$, et al. Normal human tissues, in addition to some tumors, express multiple different CD44 isoforms. Cancer Res 1994; 54:4539-46.

11. Heider KH, Horst E, van den Berg F, Hofmann M, Ponta H, Herrlich P, et al. A human homologue of the rat metastasisassociated variant of CD44 is expressed in colorectal carcinomas and adenomatous polyps. J Cell Biol 1993; 120:227-33.

12. Koopman G, Heider KH, Horst E, Adolf GR, van den Berg F, Ponta $\mathrm{H}$, et al. Activated human lymphocytes and aggressive non-Hodgkins lymphomas express a homologue of the rat metastasis-associated variant of CD44. J Exp Med 1993; 177:897-904.

13. Kan M, Aki M, Akiyama K, Naruo S, Kanayama H, Kagawa S. High-level expression of the CD44 variant sharing exon v10 in renal cancer. Jpn J Cancer Res 1995; 86:847-53.

\section{Acknowledgements}

The technical assistence of Sabine Holuba and Oliver Klenner and the secreterial assistence of Sabine Selleny are gratefully acknowledged. We thank Prof Peter Bauer and Brigitte Dillinger-Paller for statistical analysis, and Dr Karl-Heinz Heider and Dr Klaus Huber for critical reading of the manuscript.

14. Birch M, Mitchell S, Hart IR. Isolation and characterisation of human melanoma cell variants, expressing high and low levels of CD44. Cancer Res 1991; 51:6660-7.

15. Kaufmann M, Heider KH, Sinn HP, von Minckwitz G, Ponta $\mathrm{H}$, Herrlich P. CD44 variant exon epitopes in primary breast cancer and length of survival. Lancet 1995; 345:615-9.

16. Wielenga VJM, Heider KH, Offerhaus GJA, Adolf GR, van den Berg FM, Ponta H, et al. Expression of CD44 variant proteins in human colorectal cancer is related to tumor progression. Cancer Red 1993; 53:4754-6.

17. Stauder R, Eisterer W, Thaler J, Gunthert U. CD44 variant isoforms in non-Hodgkin's lymphoma: a new independent prognostic factor. Blood 1995; 85:2885-99.

18. Guo YJ, Liu G, Wang X, Jin D, Wu M, Ma J, et al. Potential use of soluble CD44 in serum as indicator of tumor burden and metastasis in patients with gastric or colon cancer. Cancer Res 1994; 65:422-6.

19. Heider KH, Mulder JWR, Ostermann E, Susani S, Patzelt E, Pals STA, et al. Splice variants of the cell surface glycoprotein CD44 associated with metastatic tumour cells are expressed in normal tissues of humans and cynomolgus monkeys. Eur $\mathrm{J}$ Cancer 1995; 31 A:2385-91.

20. Product information and manual: Bender MedSystems sCD44var (v5) ELISA.

21. Product information and manual: Bender MedSystems sCD44var (v6) ELISA.

22. Durbec P, Gennarini G, Goridis C, Rougon G. A soluble form of the F3 neuronal cell adhesion molecule promotes neurite outgrowth. J Cell Biol 1992; 117:877-87.

23. Mackay CR, Terpe HJ, Stauder R, Marston WL, Stark H, Gunthert U. Expression and modulation of CD44 variant isoforms in humans. J Cell Biol 1994; 124:71-82.

Received August 7/November 25, 1996

Corresponding author: Dr. Eva Maria Kittl, Institut für Labormedizin, Donauspital, Langobardenstraße 122, A-1220 Wien, Austria 